Лидија Тантуровска

\title{
ПОТРЕБА ОД ТЕРМИНОЛОШКИ РЕЧНИК ВО ФОЛКЛОРИСТИКАТА
}

Апстракт: Како што е познато, под термин се подразбира збор или израз што се користи како стручен назив за именување на определен поим во некоја научна област и во уметноста, а под терминологија - севкупност од термини што се користат во определена научна област, во некоја струка или дејност.

Од лингвистички аспект, се препорачува термините да имаат едно и единствено значење. термини.

Според ова, и фолклористиката, како научна област, е богата со соодветни

Во нашиот труд ќе се обидеме да ја искажеме потребата од подготвување терминолошки речник од оваа област, на македонски јазик, за да се соберат и да се дефинираат (недвосмислено) термините од фолклористиката. Потребата ќ ја илустрираме со анализирање определен број примери, а за остварување на целта (подготвување терминолошки речник) е потребно да се ангажираат фолклористи и лингвисти.

Сметаме дека за нас ќе претставува научен предизвик, а за фолклористиката одлична перспектива за понатамошен развој.

Клучни зборови: лексика, лексикографија, терминолошки речник, фолклористика.

Пријавата за темата на рефератот „Потреба од терминолошки речник во фолклористиката“ е потпишана со моето име. Дозволете ми веднаш да кажам дека овој реферат има соавтори/коавтори, а тоа се, пред сѐ, колегите од Институтот за фолклор „Марко Цепенков“, со кои сум соработувала при објавувањето на нивните трудови.

Она што сакам да го истакнам е тоа дека благодарение на односот на колегите фолклористи кон македонскиот стандарден јазик и кон неговата норма, пред нас имаме долгогодишна научна соработка, која вроди плод. Имено, голем број од јазичните грешки и јазичните недоумици, постепено, од труд во труд се надминуваа(т) и се дефинираа(т) и за многу од нив веќе се најде и постои решение. Важен заклучок е дека за да излезе добра книга (во јазична смисла) е потребно да има соработка со лекторот, односно со јазичниот редактор.

Ова е особено важно зашто во правописот и во речниците на еден јазик не може и не мора да се забележани сите јазични единици. Лекторот, односно јазичниот редактор, е тој што ги препознава, ги поправа јазичните грешки од една страна и ги канализира „новопојавените“ јазични единици во нормата на македонскиот стандарден јазик, од друга страна. Како и да е, конечната цел е да биде испочитувана нормата на македонскиот стандарден јазик, меѓу 
другото, затоа што се повикуваме и на Законот за употреба на македонскиот јазик.

Кога станува збор за фолклористиката, како наука, треба да се подвлече дека за „новите“ специфични јазични единици (најчесто од областа на лексиката, односно терминологијата) обично треба да ги решаваат тимски фолклористот и лекторот/јазичниот редактор.

Јазичните „грешки“ и пропусти во еден текст можат да бидат различни, односно на сите јазични нивоа.

По овој повод ќе дадеме по некој илустративен пример со единствена цел - да ја потврдиме нашата научноистражувачка работа за овој реферат, што не треба да се разбере, во ниту еден момент, дека станува збор за критика на авторите. Впрочем, за спроведувањето на чистотата на јазикот се одговорни, пред сѐ, јазичарите.

Можеме да почнеме со употребата на придавките фолклористички и фолклорен, за кои, веднаш треба да ја подвлечеме нивната разлика во однос на тоа што се сака да се каже затоа што првата е изведена од именката фолклористика, а втората - од фолклор. Впрочем кога зборуваме за карактеристики, различно е дали зборуваме за фолклористички или за фолклорни карактеристики.

Изведувањето на придавките е важна работа и затоа треба многу внимателно да се употребува соодветната придавка. На пример, како јазичар, (се) прашувам зошто придавката литерарен е изведена од именката литература.

Во зборообразувањето, воопшто, може да се забележи дека се јавуваат повеќе „грешки“, што е и разбирливо поради фактот што при научноистражувачката работа се користи странска (словенска и несловенска) литература, која може да повлијае при употребата на образувањето на соодветните збороформи во македонскиот јазик.

Кога сме кај зборообразувањето, можеме да споменеме уште една придавка, изведена од именката игра: игров, односно игрив, за која, со авторката, „се договоривме“ дека треба да биде игрив (јазик).

Во продолжение, како пример, ќе ја наведеме сложенката игроорец, игроорка, како и изведената придавка од неа - игроорен, -a, -о, -и. Иако постојат и сложенката и придавката, изведена од неа, во Правописниот речник, оваа сложенка долго време низ печатените трудови од Институот за фолклор била со формите: играорец, играорка ..., односно со нејзината придавка: играорен, играорна... итн. Причината за ова е очигледна, односно текстовите не се видени од лектор.

Кога зборуваме за „повторувањето на делови од стиховите“, авторот констатира дека се создавани едноделни, дводелни, троделни, четвороделни сложени форми на песни, што пак, според зборообразувањето во македонскиот јазик треба да стане збор за ... триделни и четириделни сложени форми.

Во продолжение ќе издвоиме уште неколку примери со конкретни лексеми. 
На пример, во детскиот фолклор се среќава лексемата залагалки (обично во множина). Авторите го презеле овој термин од претходната научна литература што ја користеле, а јазичарот се прашува како е изведен овој термин. За да се добие точната форма е потребно да се види дефиницијата на поимот. Според дефинициите, „залагалките претставуваат посебни форми на традиционален детски музички фолклор, односно кратки мелопоетски целини, најчесто со хумористична и со шеговна содржина, фокусирани на играта кон која тежнеат детската природа и детскиот дух“ (Величковски, 2011, 26) и „суштината на залагалката е во нивната помош за развој на говорот кај детето и за развојот на способноста за негова комуникација со надворешниот свет“ (Величковска, 2012, 24). Ако се водиме од нормата на македонскиот јазик, терминот на овие форми од традиционалниот детски музички фолкор треба да биде залажувалки (изведена од еднинската форма залажувалка) доколку сакаме да биде изведена од соодветната глаголска форма залажува. Очигледно, при објавувањето на публикациите од каде што е земен терминот, немало лектор или пак, по пат на помал отпор (,така се употребува во нашата литература“) се остава по „традиција“ терминот што се употребува(л).

Многу внимателно треба да се користи соодветна лексема кога станува збор за превод од друг јазик, на пример, од албанскиот. Авторот на текстот го користи терминот (свадбен) колач кога зборува за обред при почнувањето на свадбата во куќата на младоженецот при што ја дава и оригиналната лексема од албанскиот јазик bukë. Всушност, при преводот треба да се внимава и на културата на народот на чиј јазик се преведува. Ова би го поткрепиле со фактот што во македонската традиција обично станува збор за (свадбена) погача во обредната свадбена традиција на македонскиот народ, па лекторот би требало да сугерира на лексемата погача, наместо употребената лексема колач, која е својствена за обредна традиција на друг народ. Пожелно е во заграда да стои и оригиналната лексема. Ова е така, освен ако, навистина во рамките на албанскиот јазик, не се користи токму лексемата колач преземена од северните говори на македонскиот јазик. Дека е тоа така, потврда можат да ни бидат стиховите што се наведуваат на албански јазик, а во кои се употребува лексемата колач, со словенско потекло.

Кога зборуваме за стиховите, како материјал што е собиран од терен, па и воопшто за материјалите што се во архивата на Институтот за фолклор „Марко Цепенков“, сметаме дека треба да бидат погледнати од лектор зашто многу често, поради лекторски и коректорски грешки (направени при собирање на материјалот) може да се протолкува погрешно од страна на авторот при правењето фолклористичка научноистражувачка анализа. Според јазичарите, многу е важно дали станува збор: за лута или љута змија; за втасано или фтасано ... зашто според овие разлики можат да се следат карактеристиките на македонските говори, или пак, кога станува збор за небележење на надреден знак (отпрати не, допрати не) или постоењето на коректорска грешка (да ни дајде Весо), може да не се разбере контекстот.

Ако се вратиме на користењето лексеми од друга културолошка средина, при пишувањето научен труд на македонски, многу е важно да се преведе соодветно, односно да се даде оригиналната форма во загради за да се 
избегне нејасноста. Таков е примерот со лексемата коло кога се објаснува за обредно-магискиот карактер на формата коло на коло. Авторот може да ја даде оригиналната форма зашто станува збор за друга култура, а при објаснувањето и при дефинирањето на македонски може да ја употребува и лексемата оро, се разбира во определен контекст. Од друга страна, ако станува збор за име на некое оро, тогаш треба да се водиме според принципите на ономастиката - имињата не се преведуваат - и треба да се напише во оригинална форма според фонетската адаптација на македонскиот јазик. Како пример ќе го наведеме чочекот (во различни варијанти: чочек, чучек, ќучек, тутек), кој, ако претставува вид игра, синоним на ромска (циганска) игра, треба да биде напишано со мала буква, а ако е име на игра, тогаш како и сите имиња, треба да се напише со голема почетна буква. Значи, она што често прави забуна при лекторирањето е сознанието дали станува збор за вид на нешто или пак за име на нешто, што се поврзува со соодветно правописно бележење на малата, односно на големата почетна буква. Во таа насока се и лексемите: лазарки, иванденки, додолки, односно: џаломари/џоломари, бабари, василичари, суровари, потоа - помаци, кои не можат да се најдат во Правописниот речник на македонскиот јазик, па јазичарот, според своите познавања од правописот на македонскиот јазик, овие лексеми предлага да се пишуваат со мала буква. Така, во примерот, преземен од авторот што ја обработува оваа тема, би требало да стои: „... во обредните поворки среќаваме и низа различни маргинални или сомнителни ликови, кои не ѝ припаѓаат на локалната средина. Тоа се: Турци, Цигани, були, патувачки трговци, просјаци, бабари, порезници, крадци, војници, претставници на власта, свештеници и др.“, во зависност од тоа дали станува збор за име на народ или пак за име на етничка или на друга група.

Големата односно малата почетна буква е поврзана и со употребата на сонцето, месечината, земјата итн. во зависност од тоа дали станува збор за небеско тело или за општа именка (на пример, Сонце - како термин што спаѓa во небески тела и сл. наспрема сонце - како општа именка).

При анализата на именската група „разурнатото црковно \$воно“ станува збор за директен превод од српскиот јазик. Сугестијата останува иста: може да се даде оригиналниот назив на соодветниот јазик, а при дефинирањето и при објаснувањето треба да ни помогне културната традиција на македонскиот народ, односно да се каже дека станува збор за црковна камбана.

Особено сакаме да го истакнеме фактот дека понекогаш е многу тешко да се најде соодветен термин ако авторот, со право, покрај интернационалниот збор што се употребува во македонскиот јазик анксиозност ${ }^{\mathbf{1}}$, сака да даде и превод на македонски (на пример, за лексемите: тескоба, зебња и сл.) .

Бидејќи уште сме кај дефинирањата на лексемите (од културата од друг народ) од друг јазик на македонски јазик, ќе ги споменеме и лексемите ергенки и беќарки, кои не можат да останат во соодветните преводи на

\footnotetext{
1 Анксиозноста, обично, се дефинира како чувство на општа возбуденост, нејасен страв без очигледен надворешен повод, голем стрес и загриженост итн.
} 
македонски, со оглед на фактот што овие турцизми во македонскиот јазик се само во машки род и се однесуваат само на машки пол.

Од друга страна, пак, кај лексеми што се наоѓаат во културата кај повеќе народи, може да се јави друг проблем. Имено, тапанот, како музички инструмент го има во културата кај повеќе народи, меѓутоа, во македонската традиција дејството е изразено со глаголот чука (на тапан), а не со глаголот свири. Па, така, кога се зборува за глаголското дејство, треба да се внимава при неговата употреба.

Од заедничката работа со фолклористите може да се збогати лексичкиот фонд на македонскиот јазик. Како пример ќе ја дадеме лексемата сценка, за која авторката има дадено соодветна дефиниција.

Лекторот може да укаже и во однос, на пример, на употребата на македонски јазик (фонетски адаптирано) на името на христијанскиот светец и великомаченик Георгиј/Ѓ орѓи/Ѓ орги Победоносец (од 3/4 век).

Со овој мал број илустративни примери, сакавме да ја прикажеме потребата од интерактивната работа меѓу лекторот/јазичниот редактор и фолклористот. Од соработката произлегува дефинирање на многу јазични појави, меѓу кои и дефинирањето на термини од фолклористиката. Според ова, би било корисно да се каже што се подразбира под терминот термин. Како што е познато, под термин се подразбира збор или израз што се користи како стручен назив за именување на определен поим во некоја научна област и во уметноста, а под терминологија - севкупност од термини што се користат во определена научна област, во некоја струка или дејност (Толковен, 2014, VI: 46). Од лингвистички аспект, се препорачува термините да имаат едно и единствено значење. Следствено, и фолклористиката, како научна област, е богата со соодветни термини. Потребата од подготвување терминолошки речник од оваа област, на македонски јазик, за да се соберат и да се дефинираат (недвосмислено) термините од фолклористиката, како што може да се види, произлезе токму од соработката при јазичното средување на текстовите од фолклористиката.

Во нашето излагање, покрај терминологијата, можат да се споменат и други ,јазични проблеми“, кои, преку вакви анализи, можат да придонесат многу при јазичното средување на текстот.

На пример, многу често недоследноста во употребата на засведочените и незасведочените дејства (при употребата на граматичката категорија време) во еден текст може да прави проблем. Треба да се истакне дека може да се пишува со минато неопределно време, но во еден текст, во ист пасус, во иста реченица не треба еднаш да се употреби минато неопределено време, а друг пат - минато определено несвршено, односно свршено време. Особено треба да им се укаже на авторите дека во научен текст може да се пишува и со т.н. историско сегашно време.

Меѓутоа, кога станува збор за давање превод од друг јазик на македонски (на пример, „иницијална формула во влашката раскажувачка традиција“), многу е тешко каков став ќе заземе авторот. Имено, изразите: „Беше еден цар, имаше три сина и една ќерка“, односно „Си беше една мајка со ќерка и со тројца синови“ или пак „Си беше што не беше“ се преведени во 
духот на влашкиот јазик, односно при преводот на македонски е употребено минатото несвршено време. Ако, пак, акцентот се става на приказните како посебна „литературна норма“ со своите карактеристики, можеби би требало да се преведат овие воведни реплики со минато неопределено време, во духот на македонскиот јазик: „Си бил еден цар...“, „Си била една мајка ...“, или „Било што не било ...“ итн.

Лекторот води сметка и за многу други работи за да излезе текстот без грешка. Па, така, при цитирањето на користената литература укажува на немешањето на кириличните и латиничните библиографски единици на крајот од текстот.

Будното око на лекторот забележува и грешки од типот употреба на лексемата српскохрватски јазик надвор од контекст на југословенската заедница што постоеше до 1991 година, или од типот дека Шар Планина е највисокиот планински масив во Република Македонија.

Од овој кус преглед може да се заклучи дека е потребен терминолошки речник во секоја научна област, па и во фолклористиката, со што сметаме дека го оправдаме предложениот наслов на оваа тема.

\section{ЛИТЕРАТУРА}

ВЕЛИЧКОВСКА, Р. (2012). Македонското традиционално народно пеење (хрестоматија со мелопоетска анализа). Скопје: Мисла.

ВЕЛИЧКОВСКИ, Б. (2011). Македонски детски фолклор. Скопје: Институт за фолклор „Марко Цепенков“, Посебни изданија, Книга 81.

Толковен речник на македонскиот јазик I-VI (2003 - 2014). Скопје: Институт за македонски јазик „Крсте Мисирков“.

ШИРИЛОВА, В. (2001). Голем лексикон на странски зборови и изрази. Скопје.

Lidija Tanturovska

\section{THE NEED FOR A DICTIONARY OF FOLKLORISTICS}

\section{Summary}

As it is known, one of the definitions about "a term" is: a word or an expression that has a precise meaning in some uses or is peculiar to a science, art, profession or subject. From a linguistic point of view, it is recommended that the terms have one and only meaning.

Accordingly, folklore, as a scientific field, is also rich in appropriate terms.

In this paper we have tried to express the need to develop a dictionary of folkloristic terms in the Macedonian language, in order to collect and define (unambiguously) the terms of folklore. We illustrated the need from dictionary by analysing some examples.

We conclude that in order to prepare a dictionary of folkloristic terms both folklorists and linguists should be engaged in its preparation.

We believe that such an ordeal would be a scientific challenge both for folklorists and linguists and thus, a great prospect for future development of folkloristics. 